DOI https://doi.org/10.32837/app.v0i66.704

УДК 004.77:352.075

Н. Р. Смірнова

orcid.org/0000-0002-3815-1803

аспірантка кафедри морського та митного права

Національного університету «Одеська юридична академія»

\title{
МУНІЦИПАЛЬНІ ВЕБ-САЙТИ ЯК ІНСТРУМЕНТ СУЧАСНОГО УРЯДУВАННЯ
}

Вступ. Муніципальні сайти нині виступають одночасно в якості інструменту при здійсненні урядування та в якості засобу масової інформації («мас-медіа»). Під «мас-медіа» ("massmedia" - скорочена форма від "media of mass communication") у науковій думці розуміють сукупність методів і засобів, за допомогою яких централізовані постачальники передають, поширюють і розподіляють інформацію й інші форми комунікації.

Поняття «мас-медіа» - не новий термін. Хоча він широко використовується, але однозначного трактування цього терміну у науковій літературі поки що немає. Тому при спробах розмежування понять IKT, ЗМI, ЗМК ми стикаємося 3 тим, що вони майже тотожні, за винятком розмежувань між засобами масової інформації та засобами масової комунікації. Між мас-медіа та IKT цього розмежування, на жаль, немає. Це результат використання поруч із поняттям «медіа-простір» інших термінів в якості аналогічних або близьких за значенням, зокрема «медіа-сфера», «інформаційний простір», «інформаційно-комунікаційний простір», «мас-медійний простір» тощо.

Досліджуючи вітчизняну та зарубіжну літератури, можна зустріти різні підходи щодо визначення поняття «мас-медіа», основними з яких є соиіологічний, філософський, антропологічний і психологічний підходи. Автором психологічного підходу у визначенні мас-медіа слід вважати канадського вченого М. Маклюена. В його визначенні мас-медіа найширше зі згадуваних вище понять, оскільки воно охоплює і ЗМК, і ЗМI, і IKT. У центрі його дослідження був вплив на особистість, який здійснюють медіа як особлива форма психологічної реальності (Маклюэн, 2003).

Контроль стану соціального середовища, формування суспільної реакції на події, передача культурних цінностей, - усе це важливі соціальні функції, визначені Г. Ласвеллом, автором соціологічного підходу, до якого належать мас-медіа. Він також запропонував модель 5 питань при аналізі каналів розповсюдження інформації: хто повідомляє? щзо? по якому каналу? для кого?

Медіа-простір - це результат взаємодії ЗМК та аудиторії. Про це зазначає російський соціолог $Є$. Юдіна, прихильник антропологічного підходу при визначенні поняття «мас-медіа»: «У сучасному світі засоби масової комунікації (ЗМК), або медіа, служать не тільки засобом передачі інформації, але і механізмом формування особливої реальності, яка формулює картину світу за межами чуттєвого досвіду індивіда. Цей феномен виникає в результаті взаємодії ЗМК і аудиторії. Його можна визначити як «медіа-простір» (Yudina, 2008).

Окрему роль відіграє філософський підхід, розроблений науковцями в рамках концепції ноосфери. Відомі американські медіа-аналітики Дж. Аркіла та Д. Ронфлед вважають, що ноосфера в сучасному розумінні об'єднує такі поняття як «кіберпростір» та «інфосфера» (мас-медіа) у «всеохоплюючий простір свідомості» (Arquilla, 1999).

На рахунок сучасного медіа-простору ми впевнено можемо говорити про існування такого поняття як «національний медіа-простір». Кожна держава регулює інформаційне середовище відповідно до наявного, хоча і не ідеального законодавства, принципів і правил, враховуючи рівень розвитку IКТ. Інформаційна та комунікативна взаємодії дозволяють цій сфері розвиватися, а також задовольняти постійне зростання потреб споживачів.

Доведено, що інтерактивність та конвергентність IКТ призводять до поступового стирання меж між виробниками інформації та споживачами, розвиваючи шляхи взаємодії між суб'єк- 
тами обміну інформацією (many to many). Головними ознаками інструментів IКТ є мобільність; конвергенція (взаємопроникнення); інтерактивність.

\section{1. Муніципальні сайти як дієвий інструмент IKT}

Створення правильно побудованих сайтів міста, як показує практика зарубіжних країн, перетворює їх на дієві інструменти електронного урядування, оскільки вони є офіційним дистриб' ютором законотворчої або управлінської діяльності місцевого самоуправління (урядування). У цьому досліджені як приклади розглядатиметься організації сайтів місцевого самоврядування, тобто сайти міських рад.

Постійно зростаюча тенденція до електронного урядування на місцевому рівні полягає в розширенні можливостей доступу до публічної інформації громадянами з боку місцевого самоврядування. Категорії електронного управління, відповідно до яких можливо проаналізувати та оцінити роботу сайтів, класифікувати можна по-різному. В цьому дослідженні за основу взято уже відомий міжнародний досвід при оцінці роботи сайтів місцевого самоврядування.

Категорія зручність використання включає в себе питання традиційного оформлення веб-сторінок (наприклад, властивих для державних органів), оскільки відповідність «звичному» формату підсвідомо викликає довіру у користувача.

Категорія змісту розглядається з точки зору доступу до контактної інформації, доступу до публічних документів, таких як звіти про проведену діяльність органу місцевого самоврядування, доступ до сайту людей з обмеженими можливостями і так далі. Цей компонент оцінки є важливим для кожного веб-сайту. Якщо зміст веб-сайту не є актуальним, якщо по ньому важко орієнтуватися або якщо надана неправильна інформація, то він не виконує своє завдання незалежно від того, наскільки технологічно розвинені функції сайту.

На жаль, дуже мало органів місцевого самоврядування забезпечують доступ до сайту для осіб з обмеженими можливостями. У більшості міст Європи та Азії є веб-сторінки, які використовують бездротові технології (наприклад, повідомлення на мобільний телефон чи КПК (Personal Digital Assistant) для оновлення програм, подій).

Категорія доступності має на увазі інтерактивні служби, які дозволяють купувати або оплачувати послуги, а також можливість користувачів реєструватися і подавати заявки на муніципальні заходи або послуги в інтернеті. Так, в умовах обмеженого бюджету організація подібної інтерактивної служби проблематична, але хорошим прикладом може стати співпраця з ініціативами Open Data Access, наприклад «Штрафы UA. Проверка Авто, ОСАГО», де користувач може ввести номер постанови, суму, прізвище та пошту (для отримання повідомлення про погашення), потім провести платіж на рахунок Держказначейства через LiqPay. Нині команда займається технічною можливістю роботи з базами даних безпосередньо. В майбутньому це дозволить, крім оплати штрафів, отримувати і повідомлення про них у момент фіксації порушення. Подібна взаємодія обговорювалася 15 вересня 2020 року на онлайн-форумі, присвяченому цифровій трансформації регіонів, який було проведено за підтримки Мінцифри та EGAP.

Категорія участі передбачає залучення громадян до діяльності органів місцевого самоврядування шляхом проведення опитувань на сайті та відкритих обговорень різних проектів. Завжди важлива участь громадян у процесах прийняття рішень на місцях.

Завдяки правильно побудованим муніципальним сайтам жителі можуть безпосередньо зв'язуватися 3 державними службовцями та залишати свої відгуки. Крім того, дошки онлайн-обговорень дозволяють громадянам піднімати і обговорювати громадські питання. Актуальною залишається проблема використання IKT для активного залучення громадян до діяльності уряду та органів місцевого самоуправління.

Гарна ініціатива сторінка eCitizenIdeas (Singapure), на якій уряд публікує повідомлення про виникнення проблем або суспільні проблеми, з якими стикається місто. Надана система заохочень, щоб мотивувати громадян пропонувати свої ідеї. За допомогою цього інструменту користувачі можуть опублікувати власні ідеї та взаємодіяти з іншими. В результаті місцеве самоврядування проаналізує ідеї та відгуки громадськості і прийме остаточне рішення. Це найефективніший спосіб залучення громадян на ранніх етапах формування політики.

На прикладі офіційного сайту Херсонської міської ради (http:/ / www.city.kherson.ua) зрозумілим стає розмежування компетентностей при створенні, адмініструванні та розвитку 
сайту. Враховуючи внутрішню структуру апарату міської ради Херсону, у штаті було створено відділ відео-інформаційного та програмного забезпечення Херсонської міської ради. До компетентностей цього відділу належить адміністрування та координування роботи сайту, в той час як питання технічного забезпечення, тобто розміщення сайту на сервері та правильна робота останнього, координуються партнером-компанією IT на основі цивільного договору про надання послуг. Варто зауважити, що компанію-партнера було знайдено ще у 2001 році і з того часу провайдер не змінювався.

На сайті Херсонської міської ради, порівнюючи з практикою організації сайтів зарубіжних країн, є свої недоліки. Так, не надто зручна навігація сайту, особливо на хвилі розвитку мобільного додатку Дія, де на прикладі ініціативи «Дія. Цифрова освіта» доведено, що ознайомлення користувачів шляхом відео-роликів має більшу продуктивність, ніж залишення цього питання на самостійне ознайомлення користувачами.

Проте варто зауважити грамотний розподіл питання наповнення сайту, оскільки міська рада координує діяльність багатьох структур міста, тому правильним було розподілити обов' язки з надання контенту на відповідні структури. На сайті втілено принцип G2C - C2G шляхом створення відповідних опитувань через Гугл-форми, проте відсутня можливість відкритого громадського обговорення ініціатив міської ради на сайті міста. Тобто, будь-які звернення несуть персональний характер і спрямовуються на особу, яка займає посаду міського голови. Крім того, не повністю реалізовано принцип доступності інформації, оскільки відсутнє дублювання сторінки англійською мовою. Це обмежує можливості іноземних відвідувачів міста ознайомитися з діяльністю органів місцевого самоврядування.

У структурі органу міської ради відсутній аналітичний відділ, який мав би відповідати за результативність діяльності сайту. 3 огляду на Положення про сайт (документ знаходиться у відкритому доступі для користувачів) сторінка на цьому етапі несе за мету інформування населення міста про діяльність органу та заходи, які є важливими для херсонців (затвердження бюджету, результати проведення тих чи інших заходів).

\section{2. Конфіденційність і безпека}

3 рівнем збільшення приросту IKT в екосистемі людини та накопичення інформації збільшується і кількість загроз. Системі властиво ускладнюватися внаслідок нагромадження інформаційного аспекту. Це не тільки робить їі глобальною (відносно інформаційного світового простору), але й порушує встановлений для стабільних одиниць порядок. У зв' язку з цим виникає нагальна потреба у перегляді встановленого ззовні порядку, розширенні компетентностей контролюючих органів та інструментів контролю.

Суттєвою проблемою є той факт, що нормативно-правове забезпечення електронного урядування має здебільшого декларативний характер, адже відповідні нормативно-правові акти є стратегічними та в деяких випадках прямо пов' язаними з виконанням Угоди про асоціацію iз CC (Roshchuk, 2018). У зв'язку з цим виникає потреба більш детального дослідження питання безпеки в кіберпросторі (Бондар, Турченко, 2016). Оскільки інформація, яка знаходиться на офіційних веб-сторінках владних суб'єктів або облікові записи працівників, несуть у собі не лише загрозу розповсюдження приватної інформації, але і загрозу поширення небажаної чи соціально неприйнятної інформації, якщо це, наприклад, сайт міста.

Одним із різновидів кіберзагроз, які можуть спіткати муніципальні сайти, є кібератаки 3 метою хуліганства або ж з метою цілеспрямованого підриву роботи управлінських функцій місцевого самоврядування. Атаки можуть спричинити не лише відключення локальної служби та порушення комунікаційного принципу реалізації участі G2C (government-to-citizen), але і спричинити збитки матеріального характеру, оскільки відновлення роботи сайту може бути надзвичайно дорогим. Крім того, злом офіційного веб-сайту міста несе в собі ризик розкриття конфіденційної інформації про жителів міста.

Чи можливо мінімізувати ризики, пов'язані з використанням муніципальних сайтів? Звичайно. Насамперед шляхом посилення контролю зі сторони контролюючих суб'єктів. Слід встановити серед працівників органу місцевого самоврядування сувору політику щодо даних. Грамотне ведення та використання муніципальних сайтів дозволить збирати дані для певних цілей, не викликаючи при цьому конфронтації з боку користувачів. Як показує 
практика, позитивний настрій і симпатії до дій органів управління зменшують спроби цій владі протидіяти.

Розвиток IКТ передбачає відповідний рівень розвитку державних структур. Оскільки все ще існує проблема «старшого» покоління, де в силу обставин люди не ознайомлені або їм важко освоїти необхідні технології, слід підвищувати рівень компетентності персоналу. Варто регулярно організовувати тренінги для співробітників, присвячені основним питанням конфіденційності, безпеки та вразливості мережі, а також конкретні дії, які окремі особи можуть зробити для усунення або мінімізації ризику, включаючи внутрішні заходи, пов'язані з компетентністю службовців. Необхідно часто робити резервні копії даних. Наявність під рукою повної резервної копії даних може зменшити вплив запущеної програмної атаки. Регулярне оновлення системи безпеки допоможе запобігти елементарним загрозам.

Коли йдеться про роботу муніципальних сайтів, завжди мається на увазі професійне технічне забезпечення компанії-партнера на основі цивільного договору про надання послуг. Забезпечте дотримання партнерами, які відповідають за технічне обслуговування сайту, виконання високих стандартів конфіденційності та безпеки. Подібні заходи необхідні при введенні в дію нових програм або програмного забезпечення.

Нині в Україні необхідно прийняти міжнародний досвід спільнот із покращення безпеки і зменшення відповідних ризиків. Гарним прикладом може послугувати MANRS (Mutually Agreed Norms for Routing Security) - це глобальна ініціатива, підтримувана інтернет-спільнотою, яка надає важливі поради щодо виправлення і зменшення найбільш поширених загроз (Manager, 2020).

Висновки. Для створення більш дієвих інструментів електронного управління є необхідність проведення досліджень та аналізу отриманих даних. Вивчення практики муніципального електронного управління в усьому світі - це актуальне дослідження. Нині очевидна різниця в рівнях розвитку українського електронного урядування та організації останнього в європейських країнах.

Слід розробити комплексну політику щодо усунення розриву рівня розвитку муніципального електронного урядування в Україні та країнах Європи, на які звернений орієнтир політики нашої держави. Ця комплексна політика повинна включати нарощування потенціалів муніципалітетів, включаючи інформаційну інфраструктуру, яка існує, контент, програми та доступ до окремих осіб, а також навчання мешканців і службовців за допомогою відповідної комп'ютерної освіти.

Оцінюючи наявність перерахованих категорій на сайті міста, можна визначити рівень розвитку і відсутні елементи. В ідеалі сайт міста повинен відповідати 5 критеріям: 1) конфіденційність і безпека; 2) зручність використання; 3) зміст (наповнення сайту); 4) доступність; 5) фактор участі G2C (соціальна активність).

\section{Лimepamypa}

Ахновська I.О. (2018) Віртуальні комунікації у сімейній освіті України в контексті світових тенденцій. Науковий вісник Ужгородського національного університету. Серія: Міжнародні економічні відносини та світове господарство. Випуск 20, ч. 1, с. 27-31.

Бондар A.O., Турченко О.Г. (2016) Загрози і моделі глобальної інформаційної безпеки. URL: http\%3A\%2F\%2Fjvestnik-sss.donnu.edu.ua\%2Farticle\%2Fdownload\%2F8409\%2F8408\&usg=AOvVaw3Wi70 y3MqVFqVoiwgblyyi.

Гасимов Р.А. (2014) Інноваційні механізми взаємодії з громадськістю в системі державного управління. Вісник Київського національного університету ім. Тараса Шевченко. Серія: «Державне управління»., Вип. 2(2), с. 13-16.

Конах В.К. (2015) Виникнення та еволюція поняття «медіа-простір» у науковій думці. Вісник Дніпропетровського університету. № 2, с. 112-129.

Маклюэн М. (2003) Понимание медиа: внешние расширения человека. [перевод с англ. В. Николаева] M. : Канон-Пресс. URL: http://yanko.lib.ru/books/cultur/mcluhan-understanding_media=ann.htm.

Пономарь Н.Ф. (2008) Связь с общественностью: социально-психологические аспекты. Учебное пособие. СПб : Питер. URL: http://virtua.nsaem.ru:8001/mm/2008/000109111.pdf.

Arquilla J., Rongeldt D. (1999) The emergence of Noopolitic: toward oa American Information Strategy. SantaMonica. URL: https://apps.dtic.mil/dtic/tr/fulltext/u2/a363442.pdf. 
Baudrillard J. (2004) Symuliakry I symuliatsiya [Symulacra and Symulation], Osnovy, Kyiv.

Digital Governance in Municipalities Worldwide. URL: https://www.seoulsolution.kr/sites/default/ files/gettoknowus/Rutgers\%20SPAA_Digital\%20Governance\%20in\%20Municipalities\%20Worldwide\%20 \%282015-16\%29.pdf.

Falkheimer J., Jansoon A. (2006) Geographies of Communication: The Spatial Turn in Media Studies. Goteborg Nordicon. URL: https://www.amazon.com/Geographies-Communication-Spatial-Media-Studies/ $\mathrm{dp} / 9189471369$.

Laswell H.D. (1938) Propaganda Technique in the World War, Peter Smith, New-York. URL: https://www.abebooks.com/Propaganda-Technique-World-Lasswell-Harold-D/22724330490/bd.

Manager M. (n.d.). MANRS. Retrieved November 01, 2020. URL: https://www.manrs.org/.

Roshchuk M. (2018) Development of electronic government in Ukraine: legal aspects of providing information security. Ukrainian Scientific Journal of Information Security. Vol. 24, issue 1, p. 17-22.

Yudina E.N. (2008) The development of modern Russian media space (TV example): dissertation abstract. Moscow. Режим доступу: https://www.dissercat.com/content/razvitie-mediaprostranstva-sovremennoirossii-na-primere-televideniya.

\section{References}

Akhnovska I.O. (2018) Virtualni komunikatsii u simeinii osviti Ukrainy v konteksti svitovykh tendentsii. Naukovyi visnyk Uzhhorodskoho natsionalnoho universytetu. Seriia: Mizhnarodni ekonomichni vidnosyny ta svitove hospodarstvo. Vypusk 20, ch. 1, s. 27-31.

Arquilla J., Rongeldt D. (1999) The emergence of Noopolitic: toward oa American Information Strategy. Santa-Monica. URL: https://apps.dtic.mil/dtic/tr/fulltext/u2/a363442.pdf.

Baudrillard J. (2004) Symuliakry I symuliatsiya, Osnovy, Kyiv.

Bondar A.O., Turchenko O.H. (2016) Zahrozy i modeli hlobalnoi informatsiinoi bezpeky. URL: http\%3A\%2F\%2Fjvestnik-sss.donnu.edu.ua\%2Farticle\%2Fdownload\%2F8409\%2F8408\&usg=AOvVaw 3Wi70y3MqVFqVoiwgbIyyi.

Hasymov R.A. (2014) Innovatsiini mekhanizmy vzaiemodii z hromadkistiu v systemi derzhavnoho upravlinnia. Visnyk Kyivskoho natsionalnoho universytetu im. Tarasa Shevchenko. Seriia: "Derzhavne upravlinnia", Vyp. 2(2), s. 13-16.

Digital Governance in Municipalities Worldwide. URL: https://www.seoulsolution.kr/sites/default/ files/gettoknowus/Rutgers\%20SPAA_Digital\%20Governance $\% 20$ in $\% 20$ Municipalities $\% 20$ Worldwide $\% 20$ \%282015-16\%29.pdf.

Falkheimer J., Jansoon A. (2006) Geographies of Communication: The Spatial Turn in Media Studies. Goteborg Nordicon. URL: https://www.amazon.com/Geographies-Communication-Spatial-Media-Studies / $\mathrm{dp} / 9189471369$.

Konakh V.K. (2015) Vynyknennia ta evoliutsiia poniattia "media-prostir" v naukovii dumtsi. Visnyk Dnipropetrovskoho universytetu. № 2, s. 112-129.

Laswell H.D. (1938) Propaganda Technique in the World War, Peter Smith, New-York. URL: https:/ / www.abebooks.com/Propaganda-Technique-World-Lasswell-Harold-D/22724330490/bd.

Makliuэn M. (2003) Ponymanye medya: vneshnye rasshyrenyia cheloveka. [perevod s anhl. V. Nykolaeva] M. : Kanon-Press. URL: http://yanko.lib.ru/books/cultur/mcluhan-understanding_media=ann.htm.

Manager M. (n.d.). MANRS. Retrieved November 01, 2020. URL: https:// www.manrs.org/.

Ponomar N.F. (2008) Sviaz s obshchestvennostiu: sotsyalno-psykholohycheskye aspektb. Uchebnoe posobye. $\mathrm{SPb}$ : Pyter. URL: http://virtua.nsaem.ru:8001/mm/2008/000109111.pdf.

Roshchuk M. (2018) Development of electronic government in Ukraine: legal aspects of providing information security. Ukrainian Scientific Journal of Information Security. Vol. 24, issue 1, p. 17-22.

Yudina E.N. (2008) The development of modern Russian media space (TV example) : dissertation abstract. Moscow. Режим доступу: https://www.dissercat.com/content/razvitie-mediaprostranstva-sovremennoirossii-na-primere-televideniya.

\section{Анотація}

Смірнова Н. Р. Муніципальні веб-сайти як інструмент сучасного урядування. - Стаття.

Інформаційні та комунікаційні технології (IKT) та пов'язані з ними телекомунікації та цифровізовані джерела вважаються базою для побудови інформаційного суспільства. На стезі до побудови електронної демократії IKT виявляють себе як якісно новий фактор покращення існуючої практики урядування.

У контексті розвитку інформаційних технологій відбуваються докорінні зміни в системі забезпечення функціонування систем управління, в тому числі зміни моделей урядування та розширення 
можливостей управління на основі набутого міжнародного досвіду. У сфері досліджень електронного урядування важливим є питання інструментальної бази та законодавчого врегулювання у сфері новітніх інформаційно-комунікаційних технологій.

Дослідження, що нині існують, носять загальний характер, не акцентуючи уваги на окремих видах IKT, які по своїй природі є самостійними, вартими уваги об'єктами правового регулювання в мережі Інтернет або поза її межами. Крім того, швидкість розвитку IКТ значно перевищує можливості законотворчого потенціалу України, що потребує теоретичного висвітлення проблем, виникаючих у суміжних сферах регулювання.

Цю статтю присвячено дослідженню такого інструменту електронного урядування як веб-сторінки органів місцевого самоврядування та їх ролі при здійсненні управлінських функцій. Веб-сторінки органів місцевого самоврядування - це основа для адміністрування та залучення громадян до реалізації принципу G2C, грамотної побудови політики на початкових стадіях прийняття рішень. Органи місцевого самоврядування мають можливість покращити функціональність своїх офіційних веб-сторінок, підвищивши рівень довіри громадян до своєї діяльності.

Веб-сторінки органів державного самоврядування мають бути захищені на відповідному рівні. Маніпуляції з даними недопустимі на сторінках державних структур, де, окрім персональних даних, міститься також інформація, що може мати елементи державної таємниці. Тому у статті досліджено проблеми захисту інформації, яка міститься на офіційних веб-сторінках, і можливість вирішення проблем, пов' язаних із захистом персональних даних користувачів сайту, надано базові рекомендації щодо покращення сервісної функції веб-сторінок органів місцевого самоврядування.

Ключові слова: медіа-простір, мас-медіа, кіберпростір, ноосфера, національний медіа-простір, муніципальний сайт, електронне урядування.

\section{Summary}

Smirnova N. R. Municipal websites as a tool of modern governance. - Article.

Information and communication technologies (ICT) and related telecommunications and digitized sources are considered to be the basis for building an information society. On the path to building e-democracy, ICTs are proving to be a qualitatively new factor in improving existing governance practices.

In the context of the development of the information technologies, radical changes are taking place in the system of ensuring the functioning of management systems, including changes in governance models and the expansion of management capabilities based on international experience. In the field of e-government research, the issue of instrumental framework and legislative regulation in the field of the latest information and communication technologies are important.

The research that exists today is of a general nature, it does not focus on certain types of ICT, which by their nature are independent, noteworthy, objects of legal regulation on the Internet or outside it. In addition, the speed of ICT development far exceeds the capabilities of the legislative potential of Ukraine, which accordingly requires theoretical coverage of problems arising in related areas of regulation.

This article examines e-government tools such as local government web-sites and their role in management. Local government websites are the basis for administering and involving citizens in the implementation of the $\mathrm{G} 2 \mathrm{C}$ principle, and for sound policy-making in the early stages of decision-making. Local governments have the opportunity to improve the functionality of their official websites, thereby increasing the level of public confidence in their activities.

Websites of public self-government bodies should be protected at the appropriate level. Data manipulation is not allowed on the pages of state structures, where in addition to personal data there is also information that may contain elements of state secrets. Therefore, the article explores the problems of protection of information contained on the official web pages and the possibility of solving problems related to the protection of personal data of site users, provides basic recommendations for improving the service function of web pages of local governments.

Key words: media space, mass media, infosphere, cyberspace, national media space, municipal website, e-government. 